\title{
MULTI-ELEMENT (H,C,N,S) STABLE ISOTOPE CHARACTERISTICS OF LAMB MEAT FROM DIFFERENT EUROPEAN REGIONS
}

\author{
Camin F. ${ }^{1}$, Bontempo L. ${ }^{1}$, Heinrich K. ${ }^{2}$, Horacek M. ${ }^{3}$, Kelly S.D. ${ }^{4}$, Schlicht C. ${ }^{5}$, Thomas F. ${ }^{6}$, Monahan F.J. ${ }^{7}$, Hoogewerff J. ${ }^{8}$, Rossmann A. ${ }^{9}$
}

${ }^{1}$ IASMA Research Centre - Agrifood Department, via Mach 1, 38010 San Michele all'Adige (TN), Italy; ${ }^{2}$ Central Science Laboratory, Sand Hutton, York, UK, YO41 1LZ: ${ }^{3}$ ARC Seibersdorf Ges.mbH, Seibersdorf, Austria; Institute of Food Research, Norwich Research Park. Norwich, UK, NR4 7UA. ${ }^{5}$ LGL Bayern Dienststelle Oberschleißheim, Oberschleißheim, Germany; ${ }^{6}$ Eurofins Scientific Analytics, Rue P.A. Bobierre, BP 42301, 44323, Nantes Cedex 3, France; ' ${ }^{S}$ chool of Agriculture, Food Science and Veterinary Medicine, University College Dublin, Ireland; ${ }^{8}$ School of Chemical Sciences and Pharmacy, University of East Anglia, Norwich, UK, NR47JT Isolab GmbH, Woelkestr. 9/1, D-85301 Schweitenkirchen, Germany3

\section{INTRODUCTION}

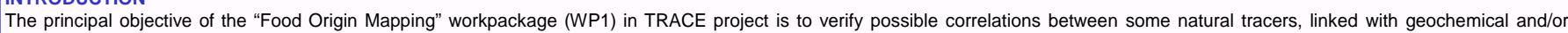

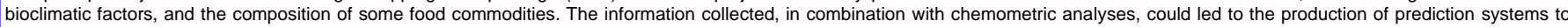
verify the declared origin of a food product.

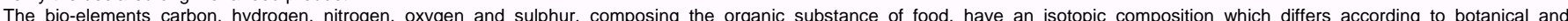
geographical factors, as well as agricultural practices $[1,2,3,4,5,6,7,8,9,10]$

In this study we present the multi-element $(\mathrm{H}, \mathrm{C}, \mathrm{N}, \mathrm{S})$ stable isotope analysis and a first interpretation of the lamb meat samples collected during 2005 within TRACE project.

\section{MATERIALS AND METHODS}

Collection and preparation of the lamb meat

The aim of TRACE project was to collect about 20 samples per year and region from 15-20 regions around Europe. Lamb meat samples were taken from the neck or other parts of the animal, by veterinary and/or public food control officials. For each sample detailed information about the origin, the feeding practice and the exact rearing location of the animals was collected. In this study only 13 sites were investigated: Allgäu (GER), Carpentras (FR), Chalkidiki (GR), Cornwall (UK), Franconia (GER), Ireland, Lakonia (GR), Limousin (FR), Orkneys (UK), Sicily (IT), Toscana (IT) and Trentino (IT) (Figure 1).

Samples were frozen at $-18^{\circ} \mathrm{C}$ until the preparation, which performed by cutting the lamb meat in small pieces and freeze-drying them. The dried pieces were homogenized and freeze-dried again; the powder obtained was extracted with petroleum ether for 6 hours in a Soxhlet-extractor. The fat free dry mass and the lipid fractions were, then, stored in a vacuum desiccator until analyses.

Stable Isotope Ratio Analysis (SIRA)

The stable isotope analyses were performed in a number of European laboratories with a range of Isotope Ratio Mass Spectrometers (IRMS) and peripherals including for $\mathrm{C}$ and $\mathrm{N}$ isotopic ratios analysis: Costech (Milan, Italy) and Thermo-Finnigan elemental analyser coupled to a Finnigan XP plus IRMS (Thermo-Finnigan GmbH, Bremen, FRG); Fisons elemental analyser coupled to a Delta S IRMS; Vario EL III elemental analyser coupled to a GVI 2003 or a GVI Isoprime IRMS. The combination of the Vario EL III (Elementar Analysensysteme GmbH, Hanau/Germany) with an IRMS-system permits, even in the case of extremely different element concentrations, the simultaneous isotope analysis of C, N and S, on a sample size of about 3 $-4 \mathrm{mg}$ measured in 4 repetitions. The hydrogen isotope analyses were performed using high temperature pyrolysis at 1350 to 1450 o $\mathrm{C}$ with a Thermo Finnigan High Temperature conversion unit or with a modified Vario EL III equipped for the pyrolysis method.

Previous inter-laboratory tests had demonstrated that preparation and stable isotopic measurement gave identical results taking into account the analytical uncertainty of the entire procedure. The uncertainty of measurements was typically $\pm 0.2 \%$ for $\delta^{13} \mathrm{C}, \pm 0.3 \%$ for $\delta^{15} \mathrm{~N}, \pm 0.4 \%$ for $\delta^{34} \mathrm{~S}$, and $\pm 3.0 \%$ for $\delta \mathrm{D}$.

\section{RESULTS}

The data obtained were submitted to statistical analysis. The data exhibited considerable variability among the different regions for all ratios, but a substantial variation was also observed within regions (Figures 2 and 3 ).

D/H:

- Greek samples show high values in agreement with the high deuterium conten measured for eastern Mediterranean precipitation and ground waters:

-Cornish, Irish and Sicilian samples: a relatively high deuterium content probably due to the closeness to the sea;

- Carpentras, Limousin, Toscana, Franconia: exhibited continental and altitude deuterium depletion effects caused by a relatively colder and more humid climate

-Trentino and Allgäu (Alpine regions), Mühlviertel: exhibited high continental and altitude effects and cold and humid climate.

${ }^{13} \mathrm{Cl}{ }^{12} \mathrm{C}$ :

- Greece, Carpentras and some samples from Limousin: a high ${ }^{13} \mathrm{C}$ content due to the maize fed supplemented to the grass-based diets of the lambs [11];

-Toscana milk fed lamb: a relatively high ${ }^{13} \mathrm{C}$ content due to the milk feeding;

-UK regions and Ireland: significantly lower values due to the influence of the high humidity of the climate on the $\mathrm{C}$ isotope fractionation during plant biosynthesis [16];

-Toscana, Orkneys and Limousin: grouped in two subset according to different $\mathrm{C}_{3}$ and $\mathrm{C}_{4}$ diets

Figures 2 and 3: Carbon vs. hydrogen and nitrogen vs. sulfur isotopic ratios of lamb meat defatted dry mass (protein)

Principal Component Analysis (PCA) was performed in order to reduce the dimensionality of the data set and to describe all the variability of the system in two dimensions. Figure 4 is the plot of the first two principal components fo samples of 2005. It results that on the basis of 4 stable isotope ratios $\left(\delta \mathrm{D}, \delta^{13} \mathrm{C}, \delta^{15} \mathrm{~N}, \delta^{34} \mathrm{~S}\right)$ it is possible to differentiate the north western regions of Orkney, Ireland and Cornwall, from Greece, from the Mediterranean areas of Sicily, Toscana, Carpentras, from the Alpine sites of Trentino and Allgäu with Franconia and Mühlviertel. The Limousin lambs, divided in two groups, are on the borderline between the Mediterranean and Alpine areas. Moreover inside the geographical groups some sites have further separated, such as in the North Western group the lambs from Orkney fed pasture are discriminated from the Irish pasture fed animals and from the group formed by Cornwall and Orkney barn fed.

The first principal component accounts for $52.5 \%$ of the variability and is loaded positively with ${ }^{13} \mathrm{C} /{ }^{12} \mathrm{C}$ and negatively with the other parameters, mainly by $\delta^{15} \mathrm{~N}$ and $\delta^{34} \mathrm{~S}$. The second principal component accounts for $29 \%$ of the variability, is loaded negatively by ${ }^{13} \mathrm{C} /{ }^{12} \mathrm{C}$ and $\mathrm{D} / \mathrm{H}$. The third principal component (not shown) accounts for $10.3 \%$ of the variability, is loaded positively with $\mathrm{D} / \mathrm{H}$, and negatively by ${ }^{34} \mathrm{~S} /{ }^{32} \mathrm{~S}$ and ${ }^{13} \mathrm{C} /{ }^{12} \mathrm{C}$. This component improves the separation between Sicily and Carpentras and between Trentino, Allgäu and Muhlviertel. The fourth principal component (not shown) accounts for $8.2 \%$ of the variability, is mainly loaded positively by ${ }^{15} \mathrm{~N} /{ }^{14} \mathrm{~N}$ and allows the separation between Toscana milk fed lambs and Toscana mix fed lambs.

LDA (not shown) has been performed as well, resulting in a cross validation result of $>80 \%$ if all regions investigated are considered.

\section{CONCLUSIONS}

The stable isotope data of hydrogen, carbon, nitrogen and sulphur could be a powerful resource for the differentiation of the geographical origin of lamb meat. If a differentiation of nearby regions or regions with similar climatic, hydrological or geographical conditions (but different geology) is necessary, the additional use of stable isotope data for the geo-element strontium (ratio ${ }^{87} \mathrm{Sr} /{ }^{86} \mathrm{Sr}$ ) has already been found to be very helpful. This approach is being investigated within the scope of the European TRACE project in addition to the integration of certain mineral content parameters.

\begin{tabular}{|c|c|}
\hline REFERENCES & $\begin{array}{l}\text { 7. Manca G., Franco M.A., Versini G., Camin F., Rossmann A., Tola A. (2006) J Dairy Sci 89: } \\
\text { 831-839 }\end{array}$ \\
\hline $\begin{array}{l}\text { 1. Kelly S.D, Heaton K., Hoogewerff J. (2005) Trends Food Sci Tech 16: } 555 \text { - } \\
\text { 567 } \\
\text { 2. Rossmann A. (2001) Food Reviews Int 17: } 347-381\end{array}$ & $\begin{array}{l}\text { 831-839 } \\
\text { 8. Pillonel L., Badertscher R., Casey M., Meyer J., Rossmann A., Schlichtherle-Cerny } \\
\text { H., Tabacchi R., Bosset J.O. (2005) Int Dairy J 15: } 547-556\end{array}$ \\
\hline $\begin{array}{l}\text { 3. Kornexl B.E., Werner R., Rossmann A., Schmidt H.-L. (1997) Z Lebensm } \\
\text { Unters Forsch 205: 19-24 }\end{array}$ & $\begin{array}{l}\text { 9. Rossmann A., Haberhauer G., Holzl S., Hom P., Pichlmayer F., Voerkelius S. (2000) } \\
\text { Eur Food Res Tech 211: } 32-40\end{array}$ \\
\hline $\begin{array}{l}\text { 4. Rossmann A., Kornexl B.E., Versini G., Pichlmayer F., Lamprecht G. (1998) J } \\
\text { Food Sci Nut 1: 9-21 }\end{array}$ & $\begin{array}{l}\text { 10. Boner M., Forstel H. (2004) Anal Bioanal Chem 378: } 301-310 \\
\text { 11. Bahar B., Monahan F., Moloney A.P., O'Kiely P., Scrimgeour C.M., Schmidt O. } \\
\text { (2005) Rap Com Mass Spec 19:1937-1942 }\end{array}$ \\
\hline $\begin{array}{l}\text { 5. Camin F., Wietzerbin K., Blanch Cortes A., Haberhauer G., Lees M., Versini } \\
\text { G. (2004) J Ag Food Chem 52: 6592-6601 }\end{array}$ & $\begin{array}{l}\text { (2005) Rap Com Mass Spec 19: 1937-1942 } \\
\text { 12. Piasentier E., Valusso R, Camin F, Versini G. (2003) Meat Sci 64:437-441 }\end{array}$ \\
\hline $\begin{array}{l}\text { 6. Manca G., Camin F., Coloru G., Del Caro A., Depentori D., Franco M.A., } \\
\text { Versini G. (2001) J Ag Food Chem 49: 1404-1409 }\end{array}$ & $\begin{array}{l}\text { 13. Winkler F.J. in Cromatography and Mass Spectrometry in Nutrition Science and } \\
\text { Food Safety, Frigerio A., Milon H. (eds) }\end{array}$ \\
\hline
\end{tabular}

